\title{
KONSTRUKSI MAKNA BAKUPUKUL MANYAPU BAGI MASYARAKAT MAMALA MALUKU
}

\author{
Sulaeman $^{1^{*}}$, Mahdi Malawat ${ }^{2}$, Darma $^{3}$ \\ ${ }^{1}$ Faculty of Ushuluddin and Dakwah, Institut Agama Islam Negeri Ambon, Indonesia \\ ${ }^{2}$ Faculty of Ushuluddin and Dakwah, Institut Agama Islam Negeri Ambon, Indonesia \\ ${ }^{3}$ Faculty of Ushuluddin and Dakwah, Institut Agama Islam Negeri Ambon, Indonesia
}

\begin{tabular}{l} 
ARTICLE INFORMATION \\
\hline \\
Submitted : 06 January 2019 \\
Review : 05 April 2019 \\
Accepted : 10 May 2019 \\
Available online: June 2019 \\
KEYWORDS \\
\hline
\end{tabular}

Meaning Construction, Bakupukul Manyapu, Mamala

\section{CORRESPONDENCE}

*E-mail:sulaeman@iainambon.ac.id

\section{A. PENDAhULUAN}

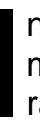
ndonesia merupakan negara berkembang, memiliki masyarakat plural dari berbagai suku, ras, agama dan bahkan keragaman budaya dengan tradisi lokal di setiap daerah di pedalaman di Indonesia. Dengan keragaman budaya dimiliki menjadi salah satu keunggulan bangsa, termasuk perkembangan pariwisata dan seni. Kebudayaan menjadi sebuah cakupan pengetahuan, keyakinan, seni, moral, tradisi dan kebiasaan yang di dalamnya terdapat nilai-nilai, norma dan simbol yang akan berpengaruh pada pola tindakan normatif manusia sebagai masyarakat. Tindakan ini sebagai penanda karakteristik berdasarkan budaya (Kuncoroyakti, 2018: 624) dan setiap budaya memiliki kearifan lokal yang menganut sistem nilai dan manfaat (Kasnadi, 2017: 151), terus menerus terikat untuk membangun identitas solidaritas sosial (Sulaeman dan Rijal, 2018: 288) sebagai upaya kebersamaan dalam pengembangan hubungan dan interaksi sesama masyarakat.

\section{A B S T R A C T}

Bakupukul manyapu is a ritual whipping each other's limbs to hurt and bleed with healing oils Mamala as nonverbal communication. The purpose of this study is to find and explain the motives, meaning and experience of Mamala society do bakupukul manyapu ritual communication. The research method using the phenomenological method that focuses on the study of meaning bakupukul manyapu ritual communication the perspective Mamala community who experience it. The research uses a qualitative approach based on constructivis paradigm with the technique of collecting data through in-depth interviews, participatory observation, study, library and documentation with supporting data based on Phenomenology perspective, symbolic interaction and social construction theory. The subject is Mamala society the perpetrator bakupukul manyapu with the purposive sampling technique. The result that Mamala society the bakupukul manyapu have a motive "because" that is the motive proud, call, test yourself, and prove, and the motive "for" attention, self-status, selfpublication, and self-identity. Bakupukul manyapu experience the pain early, bloody body lashes, whip instead of the mayhem, physical appearance, the blood is dirty, selfconfidence, and oil treatment. Bakupukul manyapu meaning is the offering, solicitation, hope, and social solidarity. Meaning construction that bakupukul manyapu is an interesting tradition, whipping each other, challenging the local wisdom, confidence, and trust in the conduct of treatment the indigenous Mamala Moluccas of tradition ritual communication.

Kearifan lokal diberlakukan masyarakat memiliki nilai-nilai moral dan sebagai pandangan hidup, menyatu dengan sistem kepercayaan dan norma diekspresikan di dalam adat (Zamzani dan Hendrawati, 2014: 40), misalnya masyarakat Maluku dengan kearifan lokal pela gandong, dua desa berbeda agama memiliki nilai-nilai moral dengan pandangan hidup pada identitas sosial hubungan ikatan saudara dan identitas religi berbeda agama (Muslim-Kristiani) berdasarkan keyakinan, simbol pengakuan perbedaan agama untuk memperkokoh hubungan antar masyarakat dan agama. Demikian pula masyarakat Tulehu memiliki nilai-nilai kearifan lokal membangun solidaritas masyarakat melalui tradisi abda'u pada proses hewan qurban. Begitu juga masyarakat Islam Mamala dengan kearifan lokal dari leluhur, seperti tradisi perpaduan nilai-nilai kearifan lokal dengan nilai-nilai agama Islam, yaitu tradisi bakupukul manyapu. 
Gambar 1. Komunikasi Ritual Bakupukul Manyapu Masyarakat Mamala

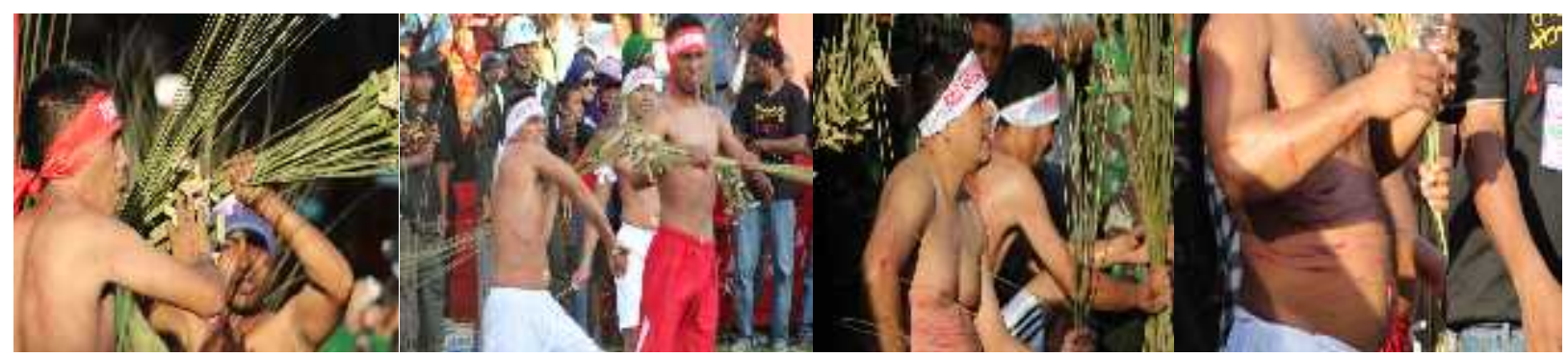

Sumber: Data primer, 2018

Bakupukul manyapu adalah komunikasi ritual masyarakat Islam di Desa Mamala, Kecamatan Leihitu, Kabupaten Maluku Tengah yang telah diwarisi dari leluhur mengenai peristiwa komunikasi nyuwelain matehu (minyak Mamala) memperkuat dan menahan sambungan rangka-rangka balok kayu masjid. Bakupukul manyapu telah dilaksanakan dari generasi kepada generasi berikutnya sampai saat ini, dengan asumsi bahwa tradisi ini merupakan komunikasi ritual yang suci, harus dilakukan setiap tahun pada hari kedelapan bulan Syawal (Sulaeman dan Rijal, 2018: 288) untuk pemenuhan jati diri sebagai upaya kebersamaan melalui kekuatan do'a dan nyuwelain matehu.

Bakupukul manyapu, ritual pada saling memukul anggota badan hingga terluka dan mengeluarkan darah dengan penyembuhan nyuwelain matehu sebagai media komunikasi nonverbal. Nyuwelain matehu menjadi salah satu alasan perlunya pemahaman mengenai keterkaitan manusia dengan ritual, diawali pemahaman mengenai kearifan lokalnya. Nyuwelain matehu sebagai media ritual, terutama konteks masyarakat Mamala dipengaruhi dan ditentukan oleh kemampuan sebagai pengobatan, disinilah pentingnya kearifan lokal dan pemaknaan simbol diciptakan masyarakat Mamala.

Kegiatan komunikasi ritual bakupukul manyapu bagi masyarakat Mamala sebagai relasi ajaran Islam dengan kearifan lokal tetap dilestarikan dan dijunjung tinggi untuk dilestarikan serta menjaga klaim kepemilikan dari masyarakat di kampung lain. Masyarakat Mamala tetap menganggap kearifan lokal tersebut dipegang teguh oleh seluruh masyarakat Mamala, karena seringkali mengalami konflik. Masyarakat Morella mengklaim kepemilikan ritual bakupukul manyapu, berakibat nyawa kedua masyarakat desa tersebut saling membunuh. Namun masyarakat Mamala setiap tahunnya tetap melakukan kegiatan komunikasi ritual yang menganggap bakupukul manyapu sebagai kearifan lokal kepemilikan masyarakat Mamala.

Bagi masyarakat Mamala, komunikasi memegang peranan penting pada ritual bakupukul manyapu. Komunikasi terjadi di antara para pelaku ritual bakupukul manyapu, terutama bagaimana memaknai dan bertindak terhadap peristiwa komunikasi sesama mereka, diwariskan, diinterpretasi dan dilaksanakan seiring dengan proses perubahan sosial terjadi dalam masyarakat (Riezali, Joebagio dan Susanto, 2018: 145), karena beberapa penelitian terdahulu dilakukan di Indonesia, seperti hasil penelitian dari Rumahuru et.al (2012) mengenai media konstruksi identitas dan ritual ma'atenu komunitas muslim Hatuhaha di Pelauw; Sakka (2015) mengenai ma'atenu media tarian di Pulau Haruku Kabupaten Maluku Tengah; Maulia dan Utari (2018) tentang Berentak dalam ritual besale pada suku batin sembilan, Kabupaten Batanghari Provinsi Jambi: kajian analisis teks dan konteks; Kuncoroyakti (2018) mengenai komunikasi ritual gerebeg di Keraton Yogyakarta; Sulaeman dan Rijal (2018) tentang simbolik komunikasi ritual ukuwala mahiate masyarakat Islam Mamala Kabupaten Maluku Tengah; dan Riezali, Joebagio, dan Susanto (2018) mengenai konstruksi makna tradisi peusijuek dalam budaya Aceh.

Penelitian terdahulu dikemukakan memiliki sejumlah kemiripan dalam aspek metode dan pendekatan digunakan dengan fenomena suatu realitas dialami masyarakat Mamala. Penelitian akan dilakukan memiliki perbedaan signifikan dengan penelitian terdahulu, mengingat aspek fokus kajian, tujuan penelitian dan karakteristik subjek ditelitinya memiliki perbedaan cukup mendasar untuk disamakan. Penelitian terdahulu sejenis ini pun dapat dijadikan referensi bagi penelitian ini terutama pada pembahasan hasil temuan penelitian yang akan dilakukan akan datang setelah data terkumpul dan pengolahan data untuk dijadikan sebagai bahan pengambilan putusan dan verifikasi ritual bakupukul manyapu.

Ritual bakupukul manyapu menggunakan pendekatan kualitatif bersifat subjektif. Untuk mengeksplorasi individu dengan interpretasi ritual bakupukul manyapu yang dilakukan masyarakat Mamala dengan perspektif konstruksi sosial dan interaksi simbolik, keduanya dianggap sebagai pelengkap satu sama lainnya. Kedua perspektif teoretis ini menjelaskan bahwa individu menentukan tujuan mereka sendiri dalam hidupnya. Mereka aktif, kreatif dan inovatif dalam berinteraksi dan berkomunikasi dengan orang lain. 
Tindakan masyarakat Mamala yang dihasilkan dari pemahaman mereka mengenai situasi internal mengenai ritual bakupukul manyapu, bukan sebagai akibat dari faktor eksternal. Konteks ini, realitas sosial dianggap sebagai intersubjektif, berbagi, dan bernegosiasi. Cukup dengan berkomunikasi dan masyarakat Mamala sebagai pelaku komunikasi ritual menyesuaikan tindakan mereka sendiri untuk memaknai ritual bakupukul manyapu.

Masyarakat Mamala dari konteks subjek, untuk menggambarkan apa yang mereka rasakan, apa yang mereka pikirkan dan apa yang mereka lakukan. Penelitian ini menggunakan metode fenomenologi, berupaya mengungkapkan realitas sosial masyarakat Mamala berdasarkan kesadaran oleh pengalaman ritual dialami. Kesadaran dan pengalaman dialami membentuk pemaknaan bahwa bakupukul manyapu merupakan tradisi yang menarik, saling mencambuk, penuh tantangan dari sisi kearifan lokal, keyakinan dan kepercayaan pengobatan dalam melakukan komunikasi ritual tradisi Mamala.

Penggunaan perspektif interaksionisme simbolik dari Blummer yang melihat realitas sosial diciptakan manusia melalui interaksi makna disampaikan secara simbolik (Mulyana dan Sulaeman, 2016: 137). Simbol tercipta dari esensi di dalam diri manusia saling berhubungan (Sulaeman dan Sulastri, 2017: 249-250). Perspektif interaksi simbolik mengutamakan bagaimana masyarakat Mamala mengkonstruksi ritual bakupukul manyapu. Diawali dengan menjelaskan dan menemukan motif, makna dan pengalaman masyarakat Mamala melakukan komunikasi ritual bakupukul manyapu dengan pendekatan penelitian kualitatif (Sulaeman, 2018: 665), pada paradigma konstruktivis dengan mengeksplorasi individu melakukan pemaknaan terhadap ritual bakupukul manyapu.

Penelitian ini menarik dilakukan dengan alasan, masyarakat Mamala melakukan komunikasi ritual bakupukul manyapu pada hari kedelapan bulan Syawal dengan memadukan pemahaman dan pengetahuan ibadah puasa Ramadhan dan puasa sunnah di bulan Syawal. Tradisi yang memadukan relasi interaksi ajaran Islam dengan kearifan lokal. Tradisi ini bukan hanya ritual seremonial belaka yang saling mencambuk hingga anggota badan terpecahpecah dan berdarah dan nyuwelain matehu sebagai minyak pengobatan, diyakini bisa menyembuhkan luka-luka. Ritual ini juga memiliki makna secara verbal maupun nonverbal dalam setiap rangkaian peristiwa komunikasi. Namun generasi milinial dan atau masyarakat sendiri sebagai pemilik kearifan lokal, belum tentu mengetahui dan memahami akan makna dan tujuan dari semua prosesi yang terdapat pada tradisi dilakukan tersebut. Alasan lainnya, masyarakat tetap mengedepankan serta melestarikan bakupukul manyapu sebagai bagian rasa cinta dan peduli pengorbanan akan tradisi yang sudah lama dimiliki, simbol identitas dirinya. Kemudian masyarakat tidak akan mudah dipengaruhi dan menghadapi tantangan globalisasi yang memiliki nilai baru dan asing, jika dapat melestarikan tradisi bakupukul manyapu.

Melalui metode fenomenologi, maka manfaat penelitian tradisi bakupukul manyapu di era digital bahwasanya dengan perkembangan zaman dan teknologi, mempengaruhi pola pikir masyarakat Mamala sehingga terjadi pergeseran nilai tradisi. Pergeseran tersebut mengalami perkembangan dari bentuk aslinya. Di era gital khususnya tradisi di Mamala akan lebih dirasakan oleh siapapun, karena tradisi dan teknologi akan saling mempengaruhi dan melengkapi. Teknologi dan tradisi memiliki peranan penting dalam kehidupan manusia. Teknologi, salah satu komponen dari tradisi. Kemudian masyarakat sebagai subjek penelitian diharapkan akan memperkaya dan mengembangkan teori komunikasi, terutama tradisi bakupukul manyapu dan komunikasi yang memperkuat landasan ilmiah dalam pengembangan ilmu komunikasi serta pengembangan akar ilmu komunikasi. Penelitian ini juga dapat menjadi referensi bagi masyarakat adat lainnya di Maluku, khususnya masyarakat Mamala yang ingin mengetahui tradisi bakupukul manyapu dan menjadikan rujukan untuk melestarikan tradisi ini.

Berdasarkan paparan yang telah dijelaskan, maka aksiologis penelitian ini memiliki nilai kebaruan dilihat dari segi pemaknaan masyarakat Mamala terhadap tradisi bakupukul manyapu dan dapat memberikan pengetahuan dan pemahaman untuk memaknai tradisi ini, sehingga memunculkan kesadaran masyarakat, khususnya generasi milineal terhadap pentingnya memahami makna yang terkandung dalam tradisi bakupukul manyapu. Memang tidaklah mudah bagi masyarakat Mamala untuk menjaga, mempertahankan dan bahkan adanya klaim kepemilikan tradisi ini dari masyarakat Morella. Ini disebabkan adanya cara pandang bahwa tradisi ini merupakan simbol jati diri bagi masyarakat Mamala.

Inilah yang menjadi latar belakang dilakukan penelitian selama delapan bulan dari tanggal 15 September 2017 hingga 10 Mei 2018. Penelitian ini memiliki tujuan untuk menemukan dan menjelaskan motif, makna dan pengalaman masyarakat Mamala melakukan komunikasi ritual bakupukul manyapu. 


\section{B. METODE PENELITIAN}

enelitian ini menggunakan paradigma konstruktivis untuk melakukan interpretasi atas bakupukul manyapu masyarakat Mamala. Interpretasi ini dilakukan peneliti atas konsep dasar bakupukul manyapu sebagai objek kajian. Peneliti dan objek penelitian akan dianggap memiliki hubungan secara timbal balik. Hasil penelitian kemudian akan mewujudkan secara literal seiring dengan berjalannya proses penelitian.

Metode digunakan adalah fenomenologi, studi yang berupa pengungkapan realitas berdasarkan kesadaran keterlibatan dialami masyarakat Mamala melakukan bakupukul manyapu. Penelitian ini merujuk pada pernyataan "... phenomenologists explore the structures of consciousness in human experience" (Creswell, 2013: 51) dengan pendekatan kualitatif interpretatif subjektif, menitiberatkan pada pengamatan dan suasana alamiah.

Kesadaran keterlibatan dialami masyarakat Mamala ini membentuk pemaknaan akan suatu realitas bakupukul manyapu. Pemaknaan ini dikaitkan dengan konsep dasar bakupukul manyapu, bisa berbentuk verbal maupun nonverbal yang dapat diamati. Masyarakat Mamala menggunakan pendekatan kualitatif
(Sulaeman, 2018) untuk menemukan dan menjelaskan mengenai motif, makna dan pengalaman bakupukul manyapu dialami. Bakupukul manyapu merupakan ritual dari serangkaian peristiwa komunikasi dialami masyarakat Mamala melalui berbagai tahapan yang tidak dapat diukur secara pasti sehingga hanya bisa dijelaskan pendekatan kualitatif yang terfokus pada prosedur penelitian yang menghasilkan data deskriptif berupa verbal maupun nonverbal dan tindakan orang diamati (Sulaeman, 2018: 662-674). Penelitian ini membutuhkan deskripsi data dan fakta diperoleh secara holistik, tidak dimaksudkan untuk menggeneralisasi.

Pendekatan kualitatif digunakan untuk mengungkapkan sebuah fenomena bakupukul manyapu terkait konstruksi makna masyarakat Mamala yang bertujuan untuk menemukan dan menjelaskan pemaknaan yang oleh sejumlah individu atau kelompok orang dianggap berasal dari masalah-masalah sosial dan kemanusiaan (Creswell, 2013: 4). Lebih lanjut dikemukakan bahwa tujuan penelitian kualitatif untuk mempertahankan bentuk dan isi tindakan dan menganalisis kuantitasnya, alih-alih mengubahnya menjadi entitas kualitatifnya (Mulyana, 2018: 150).

\section{Tabel 1.Fokus Metode Penelitian}

\section{Metode Penelitian}

Pendekatan

Penelitian

Pardigma Penelitian

Metode

Subjek Penelitian

Teknik Penentuan Informan

Pemilihan Informan

Jumlah Informan

Teknik

Pengumpulan Data

Analisis Data

\section{Keterangan}

Kualitatif sebagai pendekatan digunakan menemukan dan menjelaskan motif, makna dan pengalaman bakupukul manyapu bagi masyarakat Mamala Maluku

Konstruktivis, mengkaji pemahaman mengenai konstruksi makna bakupukul manyapu bagi masyarakat Mamala Maluku yang mengalaminya.

Fenomenologi, terfokus pada kajian pemaknaan pada komunikasi ritual bakupukul manyapu dari sudut pada keterlibatan masyarakat Mamala mengalaminya.

Keterlibatan masyarakat Mamala sebagai pelaku bakupukul manyapu.

Teknik purposive sampling, peneliti sudah menentukan sejumlah informan sesuai dengan tujuan penelitian penelitian.

Informan yang mampu berbagi menggambarkan kembali realitas sosial yang telah dialaminya, terutama sifat alamiah dan maknanya, bersedia untuk terlibat dalam kegiatan penelitian yang membutuhkan waktu lama, serta bersedia untuk diwawancara dan direkam kegiatannya selama berlangsungnya penelitian ini.

Jumlah informan sebanyak limabelas orang.

Pengamatan terlibat, wawancara mendalam, dokumentasi, dan studi kepustakaan.

Data diperoleh dianalisis berdasarkan alur pengolahan data kualitatif secara bersamaan melalui reduksi data, penyajian data, simpulan dan verifikasi untuk menjawab motif, makna dan pengalaman bakupukul manyapu bagi masyarakat Mamala Maluku. 
Subjek pada penelitian ini adalah keterlibatan masyarakat Mamala melakukan tradisi bakupukul manyapu. Penelitian ini melibatkan limabelas orang informan yang merupakan pelaku komunikasi ritual bakupukul manyapu. Teknik penentuan informan ini dengan teknik purposive sampling, dipilih berdasarkan pertimbangan dengan tujuan tertentu (Bungin, 2011: 107), merekalah yang dapat menjelaskan ataukah memberikan informasi yang akan diteliti mengenai bakupukul manyapu. Pemilihan subjek didasarkan kepada informan yang mampu menggambarkan kembali fenomena yang telah dialaminya serta bersedia untuk diwawancara dan direkan selama penelitian berlangsung.

Teknik pengumpulan data digunakan adalah pengamatan terlibat, wawancara mendalam, dan studi kepustakaan. Dalam penelitian ini, peneliti menggunakan wawancara terstruktur. Ini diterapkan karena peneliti ingin menjelajahi pengalaman, pandangan, dan pengetahuan dimiliki informan tanpa terbebani pikirannya. Ini berarti bahwa ketika peneliti melakukan proses wawancara, informan akan memiliki fleksibilitas struktur kata-kata dan ide-ide dalam menjawab pertanyaan yang diajukan peneliti.

Peneliti terjun langsung ke lapangan, bertindak sebagai pengamat untuk membuat kategori tindakan, mengamati gejala, dan merekam dan mencatat tuturan informan dengan menggunakan media seperti catatan notes, kamera dan tape recorder. Tujuannya, untuk memperoleh gambaran secara utuh dan menyeluruh mengenai bakupukul manyapu. Awalnya wawancara tidak mudah dilakukan, informan menganggap peneliti bukan etnik Maluku, khususnya etnik Mamala. Ketika mereka bersedia diwawancarai, awalnya mereka tampak gelisah. Peneliti mampu mengumpulkan data dari informan dengan cara, seperti peneliti menunjukkan kesabaran dan empati terhadap mereka.
Hasil wawacara dimudahkan dengan menggunakan bahasa lokal (Mamala), peneliti menggunakan juru bahasa, akhirnya wawancara dilakukan dengan lancar dan intim.

Hasil pengumpulan data diperoleh dari lapangan yang selanjutnya dianalisis melalui alur kegiatan pengolahan data kualitatif dilakukan secara bersamaan yaitu reduksi, penyajian, penarikan simpulan dan verifikasi data, dilakukan peneliti melalui interpretasi data sesuai konteks pertanyaan penelitian serta dihubungkan tujuan penelitian berdasarkan metode penelitian digunakan. Verifikasi ini diperoleh simpulan untuk menjawab motif, pengalaman dan makna bakupukul manyapu bagi masyarakat Mamala, diverifikasi dengan data lainnya ataupun dengan para informan penelitian.

\section{HASIL DAN PEMBAHASAN}

$\mathrm{P}$ enelitian ini bertujuan untuk menemukan dan menjelaskan bagaimana masyarakat Mamala mengkontruksi bakupukul menyapu. Konstruksi makna bakupukul manyapu bagi masyarakat Mamala terbentuk berdasarkan motif, makna dan pengalaman dan pengetahuan dimiliki yang berbeda-beda, senantiasa bisa berubah seiring dengan proses perubahan ruang dan waktu. Kesemuanya ini akan menyebabkan pemaknaan ritual akan sesuatu juga berbedabeda, seperti pemaknaan komunikasi ritual bakupukul manyapu melalui sudut pandang masyarakat Mamala yang tentunya berbeda dengan pemaknaan komunikasi ritual dihasilkan melalui pemahaman masyarakat tidak pernah keterlibatan atas berpartisipasi dalam peristiwa komunikasi ritual bakupukul manyapu, karena pemaknaan komunikasi ritual dibentuk oleh pengalaman dan pengetahuan dimiliki pelaku peristiwa komunikasi ritual. 
Diagram 1. Model Konstruksi Makna Bakupukul Manyapu bagi Masyarakat Mamala

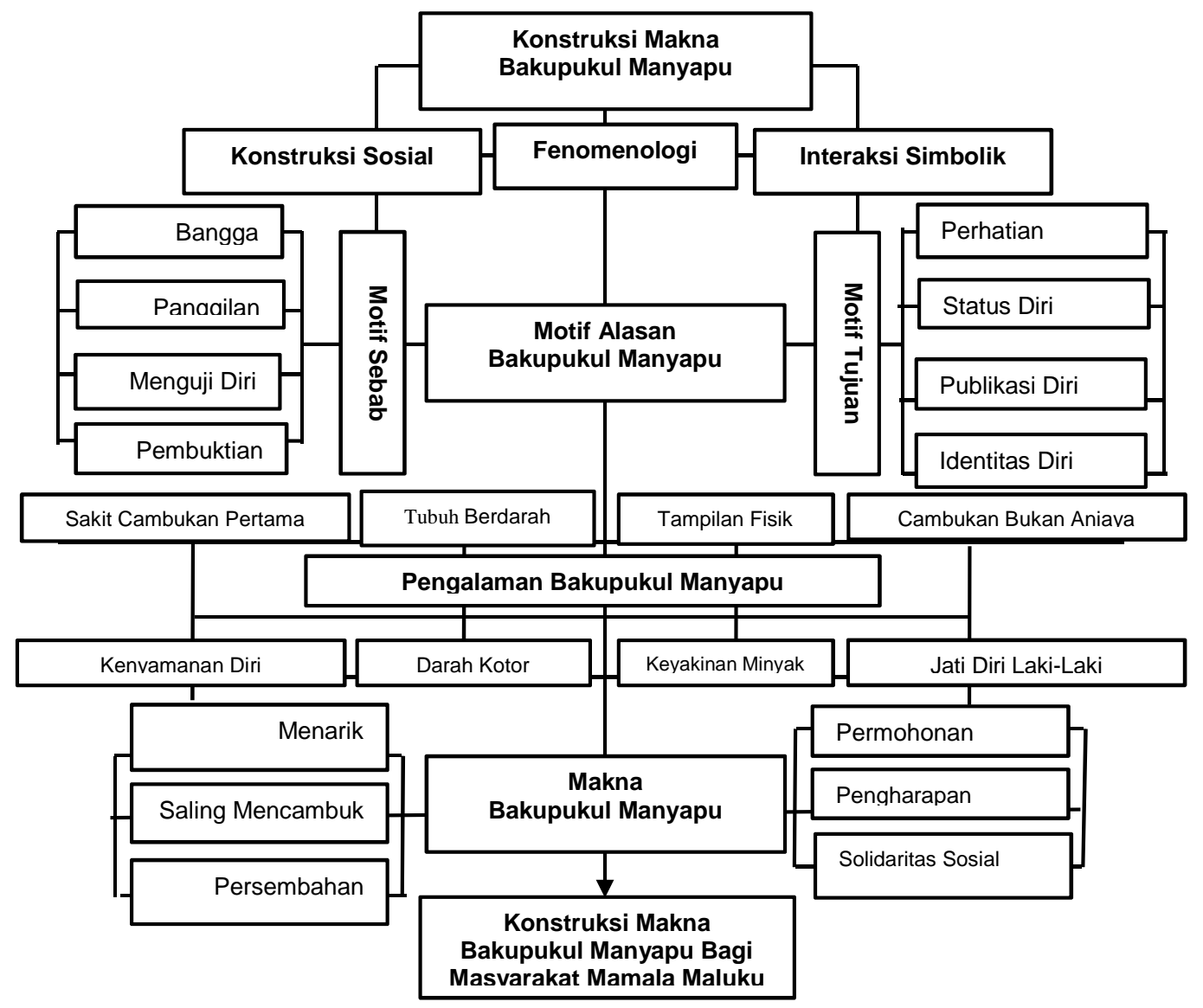

\section{MOTIF BAKUPUKUL MANYAPU}

ada setiap tindakan individu, terdapat motif menjadi orientasi dari tindakannya. Menurut Max Weber, makna dan motif subjektif inilah berhubungan langsung dengan tindakan manusia (Mulyana, 2018: 61). Motif penting dalam melihat diri masyarakat Mamala yang melatarbelakangi melakukan ritual bakupukul manyapu, karena motif dapat melihat diri masyarakat Mamala dan tindakannya "because of motive," motif sebab merujuk pada masa lalu dan tindakan "in-order-to-motive," motif tujuan merujuk pada masa depan (Schutz dalam Sulaeman, 2017 ${ }^{\mathrm{a}}$ : 65). Kedua motif ini bukan elemen terpisah satu sama lain, motif sebagai elemen terintegrasi dalam sisten dan konsisten, seperti pada tabel 2 berikut ini.

\section{Tabel 2. Penjelasan Motif Because (Karena) dan Motif In Order To (Untuk)}

\begin{tabular}{lc}
\hline \multicolumn{1}{c}{ Penjelasan Motif } & Kategori \\
\hline $\begin{array}{l}\text { Motif Bangga } \\
\text { Melakukan ritual bakupukul manyapu merasa senang, lega, dan puas yang muncul dalam hati. } \\
\text { Motif Panggilan }\end{array}$ & Because \\
$\begin{array}{l}\text { Ritual Bakupukul manyapu sebagai tugas suci yang mulia untuk pengabdian pada negeri dan harus } \\
\text { dilaksanakan dengan penuh keikhlasan serta tidak merusak lingkungan alam }\end{array}$ & Because \\
$\begin{array}{l}\text { Motif Menguji Diri } \\
\text { Memulihkan hubungan dengan Kemampuan diri melakukan ritual } \\
\text { Motif Pembuktian }\end{array}$ & Because \\
$\begin{array}{l}\text { Penyajian diri dengan kedekatan dengan sesama pelaku ritual } \\
\text { Motif Perhatian }\end{array}$ & Because \\
$\begin{array}{l}\text { Pengakuan diri dari reaksi dan rangsangan orang lain } \\
\text { Motif Status Diri }\end{array}$ & In Order To \\
$\begin{array}{l}\text { Posisi diri yang berbeda dengan orang yang tidak pernah terlibat Dallam ritual } \\
\text { Motif Publikasi Diri }\end{array}$ & In Order To \\
$\begin{array}{l}\text { Ekspresi diri untuk mengajak dan membujuk orang lain mengenail ritual kepemilikan masyarakat } \\
\text { Mamala } \\
\text { Motif Identitas Diri } \\
\text { Bentuk refleksi kesadaran diri dijadikan sebagai tugas suci untuk menyadari diri secara baik dan } \\
\text { benar }\end{array}$ & In Order To \\
\hline Sumber Ho
\end{tabular}


Motif karena (because of motive), sesuatu merujuk pada pengalaman masa lalu individu. Motif ini apa yang mendorong melatarbelakangi masyarakat Mamala untuk mengambil tindakan melakukan ritual bakupukul manyapu cukup beragam. Keragaman orientasi sebab dilatarbelakangi oleh berbagai aspek pengalaman mengkonstruksi dirinya melakukan komunikasi ritual bakupukul manyapu. Motif "karena" baku pukul manyapu masyarakat Mamala meliputi beberapa kategori di antaranya adalah motif bangga, panggilan, menguji diri, dan pembuktian.

Motif untuk (in-order-to-motive), sesuatu merujuk pada tujuan yang digambarkan sebagai maksud, rencana, harapan, minat dan sebagainya dan berorientasi masa depan. Motif ini kecenderungan pada alasan individu melakukan tindakan sebagai usaha menciptakan situasi dan kondisi diharapkan di masa akan datang atau harapan di masa akan datang. Motif tersebut teridentifikasi yang mendorong masyarakat Mamala melakukan tindakan komunikasi ritual bakupukul manyapu untuk mendapatkan manfaat cukup beragam. Keragaman orientasi tujuan dilatarbelangi berbagai aspek pengalaman komunikasi mengkonstruksi dirinya melakukan komunikasi ritual bakupukul manyapu. Motif "untuk" baku pukul manyapu masyarakat Mamala meliputi beberapa kategori di antaranya adalah motif perhatian, status diri, publikasi diri, dan identitas diri.

Kategorisasi motif sebab yang mendorong masyarakat Mamala, memperlihatkan bahwa motif melakukan ritual bakupukul manyapu cukup beragam. Keberagaman orientasi dimiliki, dilatarbelakangi oleh berbagai aspek pengalaman dan pengetahuan dimiliki serta situasi yang telah dialami. Semakin banyak pengalaman dan pengetahuan mereka yang dipandang dari sudut tertentu maka semakin terdorong melakukan komunikasi ritual bakupukul manyapu.

Pengkategorian motif ini merujuk pada identitas yang disebut Berger dan Luckmann (Sulaeman, 2017: 363) sebagai typification untuk menjelaskan konstruksi sosial dari sebuah tindakan yang sudah menjadi habitual. Hal ini sesuai juga dengan pernyataan Schutz dalam (Sulaeman, 2017 : 111-112) "in every genuine because-motivation both motivating and motivated lived experiences have the temporal character of pastnest." Motif yang disebabkan sebagai pembuktian, panggilan, bangga, dan menguji diri dilandasi oleh adanya pengalaman masa lalu masyarakat Mamala melakukan komunikasi ritual bakupukul manyapu.

Motif melandasi masyarakat Mamala sebagai subjek untuk mengambil tindakan serta memutuskan untuk melakukan komunikasi ritual bakupukul manyapu agar mendapatkan perhatian, status diri, publikasi diri, dan identitas diri. Sesungguhnya motif dimiliki masyarakat Mamala melakukan komunikasi ritual bakupukul manyapu tidak terbentuk begitu saja. Terdapat sejumlah interaksi yang terakumulasi menjadi suatu pengalaman dan bermuara pada sekumpulan pengetahuan yang akhirnya dimiliki oleh mereka.

Pengetahuan tidak serta-merta ada di dalam diri individu. Pengetahuan dihasilkan dari interaksi yang melibatkan proses berbagai informasi antara individu dengan lingkungannya. Pengetahuan itu pula melandasi terbentuknya motif untuk melakukan ritual bakupukul manyapu. Dengan kata lain, proses pembentukan motif di dalam diri mayarakat Mamala saat mereka memutuskan melakukan ritual, didasari oleh pengetahuan dan menimbulkan ekspektasi untuk mewujudkan suatu aktivitas tertentu, bisa dikategorikan ke dalam kelompok "in-order-tomotive."

Ada pernyataan menyebutkan bahwa "... Schutz posits that individuals orient to objects and actions by assuming a reciprocity of perspective with other humans" (Lindlof dalam Sulaeman, 2017 ${ }^{\mathrm{a}}$ : 122). Orientasi tindakan individu dilandasi pengetahuan dimilikinya. $\mathrm{Pe}$ ngetahuan dapat diperoleh dari pengalaman berbagi informasi dengan individu lain. Pengetahuan ini dapat mendorong timbulnya motif tertentu di dalam diri individu. Motif untuk melakukan ritual bakupukul manyapu dilandasi pengetahuan mengenai tujuan yang akan diperoleh apabila mereka melakukan ritual tersebut.

Motif dilandasi oleh adanya keinginan untuk mendapatkan tujuan dari tindakan yang akan dilakukannya sebagai motif in order to. Ini mengacu pada pernyataan bahwa "... The act thus projected in the future perfect tense and in term of which the action receives its orientation is the in order motive for actor" (Schutz dalam Sulaeman, 2017a: 122). Sebab motif ini muncul disertai adanya harapan untuk mewujudkan sebuah proyek tertentu yang manfaatnya akan diperoleh di masa akan datang apabila proyek tersebut telah terwujud.

Kecenderungan yang mendorong masyarakat Mamala untuk mengambil tindakan melakukan ritual bakupukul manyapu dapat dilihat dari motif mereka miliki. Motif merupakan konfigurasi atau konteks makna yang ada pada diri individu sebagai landasan dalam bertindak dan upayanya memaknai diri dan lingkungan. Atau dengan kata lain, motif adalah faktor pendorong individu untuk bertindak terhadap suatu objek. Seperti juga pernyataan Schutz bahwa "... Motive is meaningful ground of his behavior" (Sulaeman, 2017 a: 123). Masyarakat Mamala melakukan tindakan ritual bakupukul manyapu dilandasi oleh motif tertentu. Dengan 
mengamati motif subjek dapat diketahui kecenderungan mereka ketika melakukan tindakan ritual. Pada tindakan because motive yang menjadi stimulus bagi masyarakat Mamala untuk melakukan suatu tindakan bakupukul manyapu. Tindakan in-order-to-motive masyarakat Mamala tertarik dan memiliki keinginan untuk masa akan datang setelah melakukan komunikasi ritual bakupukul manyapu.

\section{PENGALAMAN BAKUPUKUL MANYAPU}

$\mathrm{P}$ engalaman dirasakan masyarakat Mamala sebagai informan penelitian mempunyai makna bagi mereka sendiri dan pengalaman dirasakan saling berkesinambungan satu sama lainnya. Fenomenologi mendeskripsikan makna yang berasal dari pengalaman hidup bagi beberapa masyarakat Mamala mengenai bakupukul manyapu dan berdasarkan pada pengalaman sadar dimiliki. Metode fenomenologi berasumsi bahwa individu secara aktif menginterpretasikan pengalaman-pengala- mannya dan mencoba memahami dunia dengan pengalaman pribadinya (Littlejohn, 2010: 57). Individu merupakan makhluk kreatif, berkemauan bebas dan memiliki beberapa sifat subjektif lainnya. Individu menciptakan dunianya sendiri menurut perspektifnya sendiri yang berbeda dari subjek lain, sehingga tercipta dunia subjektif dan bersifat relatif.

Berdasarkan hasil pengamatan terdapat tujuh kategori pengalaman bakupukul manyapu bagi masyarakat Mamala. Pengalaman yang diperoleh berbeda-beda setelah melakukan bakupukul manyapu dipengaruhi dari latar belakang pengalaman masyarakat Mamala itu sendiri. Pengalaman sadar mayarakat Mamala melakukan bakupukul manyapu meliputi sakit cambukan awal, tubuh berdarah, cambuk bukan aniaya, tampilan fisik, darah kotor, kenyamanan diri, dan keyakinan minyak pengobatan. Hasil dari temuan penelitian digambarkan dalam tabel 3.

\section{Tabel 3. Penjelasan Mengenai Pengalaman Bakupukul Manyapu}

\begin{tabular}{|c|c|}
\hline Kategori Pengalaman & Penjelasan Pengalaman \\
\hline Sakit Cambukan Awal & $\begin{array}{l}\text { Perasaan diri ditandai dengan kegiatan saling mencambuk dan atau pukulan } \\
\text { dengan lidi aren, awalnya dirasakan sakit }\end{array}$ \\
\hline $\begin{array}{l}\text { Tubuh Berdarah } \\
\text { Cambukan Bukan Aniaya }\end{array}$ & $\begin{array}{l}\text { Luka-luka darah yang mengalir di seluruh anggota badan } \\
\text { Saling mencambuk dan atau memukul dengan lidi aren menggunakan } \\
\text { perasaan tidak saling menganiaya para pelaku ritual }\end{array}$ \\
\hline Tampilan Fisik & $\begin{array}{l}\text { Memperlihatkan anggota badan dengan kekuatan fisik yang berbeda dengan } \\
\text { orang lain. }\end{array}$ \\
\hline Darah Kotor & $\begin{array}{l}\text { Tidak merasakan sakit sedikitpun bahkan darah yang keluar merupakan darah } \\
\text { penyakit }\end{array}$ \\
\hline Kenyamanan Diri & $\begin{array}{l}\text { Setelah melakukan ritual, perasaan diri dengan nyaman sebagai putra } \\
\text { Mamala }\end{array}$ \\
\hline Jati Diri Laki-Laki & $\begin{array}{l}\text { Keterlibatan pada ritual memunculkan jati diri sebagai laki-laki yang memiliki } \\
\text { fisik kuat }\end{array}$ \\
\hline Keyakinan Minyak Pengobatan & $\begin{array}{l}\text { Minyak Mamala digunakan untuk membasuh anggota badan yang diyakini } \\
\text { dan dipercaya bisa menyembuhkan anggota badan terluka, berdarah maupun } \\
\text { mengobati kaki patah, tulang patah, penyakit kulit, gatal-gatal, luka bakar, } \\
\text { batuk, dan penyakit kulit lainnya. }\end{array}$ \\
\hline
\end{tabular}

Sumber: Hasil penelitian

Pengalaman masyarakat Mamala muncul karena adanya aktivitas komunikasi bakupukul manyapu dilakukan. Masyarakat Mamala membangun sebuah persepsi yang sama meskipun latar belakang pengalaman mereka berbeda, ini terjadi karena komunikasi yang efektif sehingga pesan bisa tersampaikan. Pengalaman masyarakat Mamala merupakan sesuatu dialami, dan melalui pengalaman ini setiap masyarakat Mamala mendapatkan pengetahuan. Pengetahuan sendiri berlandaskan pada kesadaran melandasi pemaknaan.

Peristiwa komunikasi ritual dialami menjadi sebuah pengalaman bagi masyarakat Mamala. Pengalaman diperoleh mengandung suatu informasi atau pesan tertentu. Informasi ini akan diolah menjadi pengetahuan. Berbagai peristiwa komunikasi ritual bakupukul manyapu dialami dapat menambah pengetahuan masyarakat Mamala. Suatu peristiwa yang mengandung unsur komunikasi akan menjadi pengalaman komunikasi tersendiri bagi individu, dan pengalaman komunikasi dianggap penting akan menjadi pengalaman paling diingat dan memiliki dampak khusus bagi individu tersebut (Nurtyasrini, Hafiar, dan Askrindo, 2016: 219228).

\section{MAKNA BAKUPUKUL MANYAPU}

enomenologi dapat ditempatkan sebagai
metode yang mendeskripsikan konsep
alamiah dari persepsi individu dalam
hubungannya dengan dunia. Jadi fenomenologi
berusaha untuk memahami bagaimana
seseorang mengalami dan memberi makna pada https://doi.org/10.25077/ jantro.v21.n61.p72.2019 
sebuah pengalaman (Mulyana, 2018: 25). Makna dapat diberikan melalui pengalaman komunikasi dari setiap individu.

Masyarakat Mamala melakukan ritual sebagai cara berkomunikasi dengan Allah SWT, dan leluhurnya yang selanjutnya memandang bakupukul manyapu sebagai model sistem pengetahuan yang mempresentasikan aspek kognitif. Masyarakat menjadikan ritual sebagai model bagi jati diri untuk membangun, membina, dan melestarikan semangat solidaritas kebersamaan, kekompakkan, dan persatuan antara sesama masyarakat. Komunikasi ritual, mengacu pada pandangan dari Carey dalam (Sulaeman, 2016:18) bahwa komunikasi ritual saling berhubungan dengan komunikasi, perayaan, dan kebersamaan. Komunikasi dibangun berkaitan dengan upacara suatu masyarakat. Perayaan, biasanya dilakukan masyarakat secara bersama-sama. Ritual dilaksanakan secara kolektif dan regular agar masyarakat disegarkan dan dikembalikan akan pengetahuan dan makna-makna kolektif. Dalam konsep ini termasuk aspek metodologis, teoretis, praktek, di mana masyarakat menangkap, menginterpretasikan dan bertindak berdasarkan gejala-gejala yang masuk kepadanya.

Tampak pada masyarakat Mamala, mereka melakukan proses pemaknaan, diawali dengan melihat kategori-kategori peristiwa komunikasi ritual bakupukul manyapu bermakna. Memunculkan bentuk kategori do'a, penghormatan leluhur, solidaritas sesama masyarakat, dan permohonan kepada Allah SWT. Masingmasing individu dan atau komunitas masyarakat melakukan pemaknaan tersendiri terhadap kategori peristiwa komunikasi tersebut, walaupun hasil pemaknaan ini kemudian dipengaruhi oleh berbagai sumber, seperti cerita orang tua, cerita orang kampung, dan pengalaman komunikasi sendiri. Hasil pemaknaan tidak bisa berdirisendiri, akan terkait dengan pengaruh kelompok lain yang kemudian menjadi makna bersama. Ini pernah ditegaskan oleh Mead dalam Mulyana bahwa makna muncul dari interaksinya dengan manusia lain. Prosesnya adalah sesuatu yang sangat simbolik, yaitu proses pemaknaan yang dilakukan terhadap simbol-simbol budaya (Sulaeman dan Malawat, 2018: 75).

\section{Tabel 4. Penjelasan Mengenai Makna Bakupukul Manyapu}

\begin{tabular}{|c|c|}
\hline Kategori Makna & Penjelasan Makna \\
\hline Menarik & $\begin{array}{l}\text { Bakupukul manyapu, ritual yang menarik dan sifat tindakannya sakral dengan } \\
\text { penggunaan lidi aren. Bakupukul manyapu diidentikkan dengan kebiasaan } \\
\text { atau tindakan turun-temurun masyarakat, tindakan mengandung nilai-nilai } \\
\text { religi. }\end{array}$ \\
\hline Saling Mencambuk & $\begin{array}{l}\text { Ungkapan hati pelaku tindakan komunikasi ritual untuk menggugah rasa } \\
\text { solidaritas sosial dengan semangat juang dalam kebersamaan hidup } \\
\text { masyarakat adat }\end{array}$ \\
\hline Persembahan & $\begin{array}{l}\text { Ritual ini diyakini sebagai tempat persembahan dan permohonan ajaran } \\
\text { agama Islam dalam pembangunan masjid, kekuatan dan kesabaran untuk } \\
\text { memohon kepada Allah SWT dalam menghadapi masalah ketika terjadinya } \\
\text { balok masjid yang patah }\end{array}$ \\
\hline Permohonan & $\begin{array}{l}\text { Memanjatkan pujian dan syukuran untuk pemenuhan jati diri sebagai anak } \\
\text { negeri }\end{array}$ \\
\hline Pengharapan Kepada Allah & $\begin{array}{l}\text { Pengharapan kepada Allah SWT pemilik otoritas bumi untuk memperoleh ijin } \\
\text { dari-Nya, berupa harapan agar pelaksanaan tindakan komunikasi ritual } \\
\text { terlaksana dengan baik, tanpa ada hambatan untuk membangun solidaritas } \\
\text { kebersamaan sesama pelaku ritual }\end{array}$ \\
\hline Solidaritas Sosial & $\begin{array}{l}\text { Masyarakat adat Mamala sebagai anak negeri untuk membangun solidaritas } \\
\text { sosial dengan kebersamaan harmonis yang dijadikan sumber persatuan dan } \\
\text { kekuatan bagi kampung Mamala }\end{array}$ \\
\hline
\end{tabular}

Sumber: Hasil penelitian

Proses komunikasi ritual di masyarakat Mamala adalah sebuah proses yang berlangsung karena ada relasi masing-masing unsur pelaku komunikasi. Semua proses tersebut terikat dengan unsur-unsur pelaku komunikasi ritual. Individu akan terikat dengan pengalaman yang disampaikan orang tuanya, baik dalam bentuk penuturan langsung, bercerita, menyuruh ikut terlibat dalam ritual, ataupun melihat langsung ritual tersebut. Apabila hal ini tidak terjadi, maka kesepakatan pemaknaan akan berbeda dan keutuhan komunikasi ritual masyarakat akan terganggu. Begitu juga dengan dari orang-orang kampung, seperti obrolan sesama teman dan atau tetangga sesama komunitas masyarakat.

Proses komunikasi berlangsung rapat dan dekat, dan selalu menghubungkan dengan peristiwa komunikasi ritual bakupukul manyapu. Kerapatan hubungan dan kedekatan secara emosional menjadi faktor penting dalam komunikasi ritual di masyarakat Mamala. Faktor ini berkaitan erat sekali dengan konteks masyarakat Mamala dan ikatan kekerabatan yang terjalin. Bisa dikatakan bahwa masyarakat SULAEMAN 
Mamala adalah sebuah komunitas adat, masih mempertahankan kebudayaan berdasarkan kepercayaan agama Islam yang mereka anut. Hadikusuma (dalam Sulaeman, 2016: 65), masyarakat adat sebagai satu kesatuan hidup manusia yang berinteraksi satu sama lain menurut sistem adat tertentu, sifatnya terusmenerus dan terikat dengan rasa identitas bersama. Komunitas masyarakat Tulehu ini adalah penting dalam memahami berbagai persepsi terhadap kearifan lokal dan kemudian mengembangkan pada bentuk strategi komunikasi ritual bakupukul manyapu.

Pelaksanaan tindakan komunikasi bakupukul manyapu, dilakukan setelah pelaksanaan shalat subuh secara berjamaah di masjid, tarian hadrat, manuhua, dan alifuru. Tepatnya di waktu subuh hari pada tanggal delapan Syawal, Upu Latu Tua, parenta syara, tokoh adat, dan masyarakat Mamala melaksanakan shalat subuh secara berjamaah di masjid al-Muhibbin Desa Mamala. Dilanjutkan pembacaan salawat, zikir dan do'a (tahlilan) dengan niat ditujukan kepada Rasulullah SAW, keluarga, sahabat, dan seluruh umat Islam, khususnya ditujukan kepada arwah leluhur dan ataupun orang yang sudah meninggal dunia, mereka itulah orang yang telah mendirikan Desa Mamala, dan mendirikan masjid. Pembacaan salawat Nabi Muhammad SAW, zikir, dan tahlilan memiliki makna berupa harapan agar pelaksanaan tindakan komunikasi ritual terlaksana dengan baik, tanpa ada hambatan untuk membangun solidaritas kebersamaan sesama pelaku ritual.

Pelaku ritual menggunakan simbol komunikasi nonverbal dimiliki pelaku ritual, seperti memakai celana pendek dan ikat kepala warna merah dan putih, tidak memakai baju untuk menutup badan, dan lidi aren. Tindakan ritual memungkinkan para pelakunya berbagi komitmen, emosional dan menjadi perekat bagi kepaduan mereka, juga sebagai pengabdian kepada kelompok. Lebih lanjut ditegaskan lagi bahwa bukanlah substansi kegiatan ritual itu sendiri yang paling penting, melainkan perasaan senasib yang menyertainya (Mulyana, 2015: 43). Ritual ini diyakini sebagai tempat persembahan dan permohonan ajaran agama Islam dalam pembangunan masjid, kekuatan dan kesabaran untuk memohon kepada Allah SWT dalam menghadapi masalah ketika terjadinya balok masjid yang patah. Ritual ini juga dimaknai untuk memanjatkan pujian dan syukuran untuk pemenuhan jati diri sebagai anak negeri.

Tindakan komunikasi ritual dimaknai untuk saling membangun kebersamaan masyarakat Mamala. Ini merupakan ungkapan hati pelaku tindakan komunikasi ritual untuk mempersembahkan dan memohon kepada Allah SWT dengan semangat juang dalam kebersamaan hidup masyarakat. Diharapkan agar para pelaku ritual tidak akan mengalami kecurangan dalam tindakan ritual. Seluruh anggota tubuh-badan pelaku ritual terpecah-pecah dan atau berdarah akibat cambukan dan atau pukulan dengan lidi aren. Luka-luka darah yang mengalir di seluruh anggota badan pelaku tindakan komunikasi ritual, tidak merasakan sakit sedikitpun bahkan darah yang keluar merupakan darah penyakit. Selain itu, peserta komunikasi ritual memiliki komunikasi intrapribadi semangat juang ketika mendengar bunyi rebana.

Melalui ritual ini, pemaknaan tindakan komunikasi memiliki tindakan ekspresif untuk membangun, membina, menjaga, dan melestarikan semangat solidaritas, kebersamaan, kekompakkan, dan persatuan antara sesama masyarakat adat. Berorientasi kepada pemenuhi jati diri sebagai anak negeri, setiap masyarakat kembali menyadari eksistensi dirinya dalam dunia, baik dalam konteks bagaimana berinteraksi dengan Allah SWT, dengan sesama maupun dengan menjaga kearifan lokal terhadap klaim kepemilikan dari kampung lain.

Makna bakupukul manyapu pada ritual minyak pengobatan, tergambar dalam tindakan simbolik, tidak lepas dari peranan Imam Tunny dan keturunannya agar Allah SWT menerima amalan dan menempatkan mereka di sisi-Nya. Ritual minyak pengobatan sebagai sebuah sistem komunikasi yang dimaknai secara kultural memiliki fungsi dan bentuk penjagaan moral dan perilaku, memperkuat hubungan emosional (Humaeni, 2015: 185). Ritual tersebut merupakan tindakan dari tindakan Imam Tunny dan keturunannya dalam berkomunikasi dengan sesamanya dan atau Allah SWT. Interpretasi atas ritual minyak pengobatan terhadap perilaku masyarakat Mamala yang terlibat selama interaksi ritual. Simbolik hati bersih dari orang yang mengerjakan mengandung pesan komunikasi verbal dan nonverbal meniupkan do'a pada nyuwelain matehu.

Kekhasan nyuwelain matehu tidak dapat diperjual-belikan dan dilarang untuk meminta bayaran atas pekerjaan pembuatan nyuwelain matehu untuk dimanfaatkan bagi masyarakat adat untuk dijadikan pengobatan. Masyarakat adat memiliki sikap dan nilai kearifan lokal menunjukkan keikhlasan tanpa menyebut sebagai imbalan untuk pengerjaaan minyak. Nyuwelain matehu merupakan simbolik komunikasi nonverbal yang digunakan untuk menyembuhkan kaki patah, tulang patah, penyakit kulit, gatal-gatal, luka bakar, batuk, dan penyakit kulit lainnya.

Pengobatan para pelaku tindakan komunikasi bakupukul manyapu merupakan peristiwa komunikasi ritual yang paling akhir dari keseluruhan siklus ritual yang dilaksanakan di alun-alun Masjid al-Muhibbin yang diyakini sebagai tempat persembahan, pengharapan, dan permohonan ajaran agama Islam dalam pembangunan masjid, kekuatan dan kesabaran spiritual untuk memohon kepada Allah SWT. Ritual ini merupakan ritual pengobatan 
membasuh anggota badan dengan nyuwelain matehu yang diyakini dan dipercaya bisa menyembuhkan anggota badan terluka, berdarah maupun mengobati kaki patah, tulang patah, penyakit kulit, gatal-gatal, luka bakar, batuk, dan penyakit kulit lainnya.

Ritual pengobatan biasanya melibatkan pelaku tindakan komunikasi, dikoordinasi pimpinan ritual. Pelaku komunikasinya pada saat ritual, seluruh anggota tubuh-badan terpecahpecah dan atau berdarah akibat cambukan dan atau pukulan dengan lidi aren. Luka-luka darah yang mengalir di seluruh anggota badan pelaku komunikasi ritual, tidak merasakan sakit sedikitpun bahkan darah yang keluar merupakan darah penyakit. Pelaku komunikasi ritual memiliki komunikasi intrapribadi semangat juang ketika mendengar rebana sebagai simbol membasuh anggota badannya dengan nyuwelain matehu sebagai minyak pengobatan, diyakini bisa menyembuhkan luka-luka.

Ritual bakupukul manyapu diidentikkan dengan kebiasaan atau tindakan turun-temurun masyarakat adat, tindakan formal dan juga mengandung nilai-nilai religi. Ritual ini dipahami sebagai pertunjukan dan atau atraksi secara sukarela dilakukan masyarakat Mamala yang telah memenuhi syarat mengikuti ritual bakupukul manyapu dengan menampakkan nilai-nilai baru yang mampu menggugah rasa solidaritas sosial masyarakat. Caranya adalah dengan memperkuat kembali nilai-nilai religi dan prinsip-prinsip hidup masyarakat. Ritual ini merupakan media tradisional berupa kebijakan lokal hubungan sesama manusia untuk mengatasi pertikaian, menjaga eksistensi negeri dari klain-klain kearifan lokal dari kampung lain, membangun, membina dan mengembangkan hubungan harmonis, persembahan dan permohonan kepada Allah SWT, dan membangun solidaritas sosial masyarakat adat Mamala.

\section{KESIMPULAN}

$\mathrm{M}$ asyarakat Mamala sebagai subjek penelitian telah mengkonstruksi komunikasi ritual bakupukul manyapu dengan berbagai keragaman motif, makna, dan pengalaman dialaminya. Masyarakat Mamala dapat memberikan motif, makna, dan pengalaman tertentu mengenai apa dialami, dirasakan, dan dilakukan berdasarkan metode fenomenologi.

Beberapa temuan menjelaskan bahwa bakupukul manyapu masyarakat Mamala memiliki motif "karena" bangga, panggilan, menguji diri, dan pembuktian, dan motif "untuk" perhatian, status diri, publikasi diri, dan identitas diri. Pengalaman bakupukul manyapu menunjukkan sakit cambukan awal, tubuh berdarah, cambuk bukan aniaya, tampilan fisik, darah kotor, kenyamanan diri, dan keyakinan minyak pengobatan. Makna bakupukul manyapu adalah persembahan, permohonan, pengharapan, dan solidaritas sosial. Konstruksi makna yang terbentuk bahwa bakupukul manyapu adalah tradisi yang menarik, saling mencambuk, penuh tantangan dari sisi kearifan lokal, keyakinan dan kepercayaan pengobatan dalam melakukan komunikasi ritual tradisi adat Mamala Maluku.

Rekomendasi dari konteks teoretis bahwa penelitian yang sifatnya alamiah atau subjektivitas dapat ditinjaun pada aspek lain dengan menggunakan teoretis komunikasi yang sesuai dengan fenomena yang diteliti. Bahwa dalam pendekatan kualitatif memberikan kebermaknaan tersendiri sehingga konstruksi makna mengenai bakupukul manyapu ini bisa dikaji dari aspek teoretis komunikasi lainnya. Penelitian pendekatan kualitatif ini juga dapat menjadi pendekatan penguatan nilai-nilai dan norma kearifan lokal masyarakat Mamala. Ini diharapkan masyarakat Mamala terus melestarikan ritual bakupukul manyapu dan menjadi kekhasan komunikasi ritual di Maluku, mengingat semakin banyaknya pengaruh globalisasi di era digital. Melalui penelitian ini diharapkan pihak terkait, terutama bidang budaya dan pariwisata perlu melestarikan dan memperkenal ritual bakupukul manyapu di masyarakat dunia dan atau memasukan dalam budaya internasional yang dipatentkan.

\section{E. UCAPAN TERIMAKASIH}

$\mathrm{P}$ eneliti mengucapkan terima kasih kepada Pemerintahan Desa Mamala, Kecamatan Leihitu, Kabupaten Maluku Tengah, Provinsi Maluku, masyarakat yang telah memberikan bantuan dan kerjasamanya sehingga penelitian ini dapat terlaksana dengan baik.

\section{DAFTAR PUSTAKA}

Bungin, B. (2011). Penelitian Kualitatif: Komunikasi, Ekonomi, Kebijakan Publik, dan Ilmu Sosial Lainnya. Edisi II, Cet. V, Jakarta: Kencana.

Creswell, J.W. (2013). Qualitative Inquiry and Research Design: Choosing Among Five Approaches. California: Sage Publication. 
Humaeni, A. (2015). Tabu Perempuan dalam Budaya Masyarakat Banten. Jurnal Humaniora, 27 (2), 174-185. doi:10.22146/jh.v27i2.10585.

Kasnadi. (2017). Nilai Religi: Sebuah Kearifan Lokal dalam Cerita Rakyat Ponorogo. IBDA' Jurnal Kebudayaan Islam, 15 (1), 149-179. doi:10.24090/IBDA.V15I1.736.

Kuncoroyakti, Y. (2018). Komunikasi Ritual Garebeg di Keraton Yogyakarta. Jurnal Aspikom, 3 (4), 623-634. doi: 10.24329 /aspikom.v3i4.189.

Littlejohn, W. S. (2010). Theories of human communication. California: Belmont.

Mulia, I. S., \& I. Dewa, A. S. U. (2018). Berentak dalam Ritual Besale pada Suku Batin Sembilan Kabupaten Batanghari Provinsi Jambi: Kajian Analisis Teks dan Konteks. Jurnal Antroplogi: Isu-Isu Sosial Budaya, 20 (2), 119-128. doi: 10.25077/jantro. v20.n2.p119-128.2018.

Mulyana, D. (2015). Nuansa-Nuansa Komunikasi Menoropong Politik dan Budaya Komunikasi Masyarakat Kontemporer. Bandung: Remaja Rosdakarya, 2015.

Mulyana, D., \& Sulaeman. (2016) "People with Lobster-Claw Syndrome: A Study of Oligodactyly Sufferers and their Communication Experiences in the Village of Ulutaue, South Sulawesi, Indonesia," Mediterranean Journal of Social Sciences, 7 (1) S1, 136-144. doi: 10.5901/mjss. 2016.v7n1s1p136.

Mulyana, D. (2018). Metodologi Penelitian Kualitatif: Paradigma Baru IImu Komunikasi dan IImu Sosial Lainnya. Bandung: Remaja Rosdakarya.

Nurtyasrini, S., Hanny, H; Askrindo. S. (2016). Pengalaman Komunikasi Pemulung Tentang Pemeliharaan Kesehatan Diri dan Lingkungan di TPA Bantar Gebang. Jurnal Kajian Komunikasi, 4 (2), 119-228. doi: 10.24198/jkk.vol4n2.9

Riezali, C., Hermanu, J., \& Susanto. (2018). Konstruksi Makna Tradisi Peusijuek dalam Budaya Aceh. Jurnal Antroplogi: Isu-Isu Sosial Budaya, 20 (2), 145-155. doi: 10.25077/jantro.v20.n2.p145-155.2018.

Rumahuru, Y. Z., et., (2012). Ritual Ma'atenu sebagai Media Konstruksi Identitas Komunitas Muslim Hatuhaha di Pelauw Maluku Tengah. Jurnal Kawistara, 2 (1), 36-47. doi: 10.22146/kawistara. 3949.

Sakka, L. (2015). Tarian Ma'atenu di Pulau Haruku Kabupaten Maluku Tengah. Jurnal al-Qalam, 21 (2), 291-302. doi: 10.31969/alq.v21i2.232.

Sulaeman. (2016). Komunikasi Lingkungan: Fenomena Suku Naula di Pedesaan. Cet. I, Ambon: LP2M IAIN Ambon.

Sulaeman., \& Irta, S. (2017). Motif Da'i Berdakwah di Kota Ambon. Afkaruna: Indonesian Interdisciplinary Journal of Islamic Studies, 13 (2), 240-264. doi: 10.18196/AllJIS.2017.0074.

Sulaeman. (2017). Makna Perempuan Memilih Profesi Jurnalis di Kota Ambon. Prosiding Konferensi Nasional Komunikasi Ikatan Sarjana Komunikasi Indonesia, 1 (1), 358-367. doi: 10.25008/pknk.v1i1.105.

Sulaeman. $\left(2017^{\mathrm{a}}\right)$. Jurnalis Perempuan. Cet. I, Ambon: LP2M IAIN Ambon.

Sulaeman., \& Muhammad, R. (2018). Simbolik Komunikasi Ritual Ukuwala Mahiate Masyarakat Islam Mamala Kabupaten Maluku Tengah. Ibda: Jurnal Kajian Islam dan Budaya, 16 (2), 287-302. doi: 10.24090/IBDA.V16i2.1234.

Sulaeman. (2018). Dramaturgi Penyandang Oligodaktili. Jurnal Aspikom, 3 (4), 662-674. doi: 10.24329/aspikom.v3i4.270.

Sulaeman., \& Mahdi, M. (2018). Bakupukul Manyapu: Komunikasi Ritual Masyarakat Adat Mamala. Cet. I, Ambon: LP2M IAIN Ambon.

Zamzami, L., \& Hendrawati. (2014). Kearifan Budaya Lokal Masyarakat Maritim Untuk Upaya Mitigasi Bencana di Sumatera Barat. Jurnal Antroplogi: Isu-Isu Sosial Budaya, 16 (1), 37-48. doi: 10.25077/jantro.v16.n1.p37-48.2014. 